\title{
PENDEKATAN MISSOURI MATHEMATICS PROJECT BERORIENTASI PAKEMI DALAM UPAYA MEMOTIVASI KREATIVITAS MAHASISWA PRODI PGSD UNIVERSITAS KANJURUHAN MALANG
}

\author{
I Ketut Suastika dan Wisulah \\ Dosen PGSD Universitas Kanjuruhan Malang \\ Email: Suastika_cipi@yahoo.co.id
}

\begin{abstract}
Abstrak
Dari observasi dan refleksi awal penulis sebagai dosen yang mengampu mata kuliah pembelajaran dan sebagai dosen pembimbing Praktek Pengalaman Lapangan sering menemukan bahwa mahasiswa praktikan cenderung kurang menguasai strategi pembelajaran matematika yang berkenaan dengan penerapan model atau metode pembelajaran yang relevan. Padahal, untuk mencapai suatu Standart Kompetensi, Kompetensi Dasar, atau indikator pembelajaran tertentu seharusnya guru mampu memilih, merancang atau memadukan suatu model pembelajaran yang sesuai dan dapat dilaksanakan pada latar, jenjang, situasi, dan kondisi sekolah. Oleh karena itu, penulis tertarik untuk melaksanakan Penelitian Tindakan Kelas (PTK) yang mengadopsi langkah-langkah pembelajaran Missouri Mathematics Project (MMP) Berorientasi PAKEMIdalam Upaya Memotivasi Kreativitas mahasiswa Prodi PGSD pada matakuliah Pengembangan Pembelajaran Matematika.
\end{abstract}

Kata Kunci: Pendekatan Missouri Mathematics Project, PAKEMI, Kreativitas.

\begin{abstract}
From observation and early reflection writer as a lecturer that administer the course of learning and as a supervisor Practice Field Experience often find that students tend to be less mastered mathematics learning strategy with regard to the application of the model or the relevant learning methods. In fact, to achieve a Standard Competency, Basic Competency, or specific learning indicators should the teacher is able to choose, design or integrate a learning model that is appropriate and can be executed in the background, level, circumstances, and conditions of the school.Therefore, the authors are interested to implement the Action Research (PTK ) that adopt learning steps Missouri Mathematics Project ( MMP) Oriented PAKEMI in Motivating Creativity Effort students Prodi PGSD on Development of Mathematics Learning courses.
\end{abstract}

\section{Keywords: Missouri Mathematics Project Approach, PAKEMI, Creativity.}

Tugas utama para guru matematika adalah membimbing para pebelajar tentang bagaimana belajar yang sesungguhnya, bagaimana belajar untuk mendapatkan informasi, ide-ide, keterampilan-keterampilan, nilai-nilai untuk memecahkan masalah yang mereka hadapi dalam kehidupan seharihari. Selain itu juga mengarahkan pebelajar untuk belajar bernalar secara logis, berpikir kritis dan mengemukakan pendapat secara sistematis. Yang menjadi pertanyaan adalah: "Apakah yang sudah kita lakukan selama proses pembelajaran di kelas telah sesuai dengan yang dibutuhkan pebelajar?” .Suatu pertanyaan yang menggiring kita sebagai guru matematika untuk merefleksi proses dan hasil pembelajaran yang kita lakukan selama ini.

Pada masa lalu, dan bahkan yang terjadi pada saat ini kebanyakanguru matematika memulai proses pembelajaran dengan membahas definisi, lalu membuktikan atau menyampaikan rumus-rumus yang terkait dengan topik tertentu, lalu membahas contoh-contoh soal diakhiri dengan meminta para 
pebelajar untuk mengerjakan soal-soal latihan. Dengan pembelajaran seperti ini, para guruakan mengontrol secara penuh materi serta metode penyampaiannya. Akibatnya proses pembelajaran di kelas menjadi proses mengikuti langkahlangkah, aturan-aturan, serta contohcontoh yang diberikan guru. Seorang siswa dinilai telah menguasi materi, jika ia mampu mengingat dan mengaplikasikan aturan-aturan, langkah-langkah secara prosedural sesuai dengan langkahlangkah yang dicontohkan oleh gurunya.

Pembelajaran seperti digambarkan di atas dapat dikatakan lebih menekankan kepada para siswa untuk mengingat (memorizing) atau menghafal (rotelearning) dan kurang bahkan tidak melatih siswa untuk bernalar (reasoning), memecahkan masalah (problem-solving), ataupun pada pemahaman (understanding). Dengan pembelajaran seperti itu, kadar keaktifan siswa menjadi rendah, tidak menutup kemungkinan siswa hanya menggunakan kemampuan berpikir tingkat rendah (low under thinking skill).

Sejalan dengan munculnya teori belajar Konstruktivisme Bodner (dalam TIM P3G Mat, 2004) suatu paham yang menyatakan bahwa pengetahuan akan tersusun atau terbangun di dalam pikiran siswa sendiri ketika ia berupaya untuk mengorganisasikan pengalaman barunya berdasar pada kerangka kognitif yang sudah ada di dalam pikirannya. Dengan demikian pengetahuan tidak dapat dipindahkan begitu saja dari otak seorang guru ke otak pebelajarnya. Seorang pebelajar perlu membangun pengetahuan di dalam otaknya sendiri-sendiri. Karenanya pembelajaran dengan pemberitahuan tidak cocok untuk sebagian besar materi matematika.

Dari observasi dan refleksi awal penulis sebagai dosen yang mengampu mata kuliah pembelajaran dan sebagai dosen pembimbing Praktek Pengalaman Lapangan, sering menemukan bahwa mahasiswa praktikan cenderung kurang menguasai strategi pembelajaran matematika yang berkenaan dengan penerapan model atau metode pembelajaran yang relevan. Padahal, untuk mencapai suatu Standart Kompetensi, Kompetensi Dasar, atau indikator pembelajaran tertentu seharusnya guru mampu memilih, merancang atau memadukan suatu model pembelajaran yang sesuai, dan dapat dilaksanakan pada latar, jenjang, situasi dan kondisi sekolah.

Mengacu paparan di atas peneliti mencoba merancang suatu pendekatan pembelajaran matematika yang kontekstual berorientasi PAKEMI dikemas dalam Rancangan Penelitian Tindakan Kelas (PTK) yang mengadopsi langkahlangkah pembelajaran Missouri Mathematics Project (MMP).

Dalam suatu proses pembelajaran terdapat berbagai komponen pembelajaran yang harus dikembangkan dalam upaya mendukung tercapainya tujuan pembelajaran dan keberhasilan siswa dalam belajar. Komponen-komponen tersebut diantaranya guru, siswa, model pembelajaran, metode pembelajaran, serta sumber dan media pembelajaran (Rohaeti, 2009:13). Sebagai salah satu komponen pembelajaran, pemilihan model pembelajaran akan sangat menunjang pencapaian tujuan pembelajaran. Saat ini terdapat berbagai macam model pembelajaran yang dapat diterapkan 
dalam pembelajaran matematika di kelas. Salah satu diantaranya adalah model pembelajaran MMP.

MMP adalah salah satu pendekatan pembelajaran matematika yang memadukan beberapa model pada suatu proses pembelajaran (TIM P3G:2004). Ada 5 langkah yang harus dilalui, yaitu:

Langkah 1 : Review

- Meninjau ulang pelajaran yang lalu yang terkait dengan materi yang akan dibahas

- Motivasi dan menyampaikan tujuan pembelajaran

- Membahas PR pelajaran yang lalu atau menampilkan masalah kontekstual berkenaan dengan konsep yang akan dibahas

Langkah 2 : Pengembangan

- Penyajian ide baru perluasan konsep matematika yang telah dipelajari

- Penjelasan, diskusi atau demonstrasi dengan contoh konkret yang sifatnya pictorial dan simbolik

Langkah 3 : Belajar Kooperatif

- Melakukan proses pembelajaran dengan menerapkan model pembelajaran Kooperatif terpilih

Langkah 4 : Seatwork

- Siswa bekerja sendiri atau berpasangan untuk latihan atau perluasan konsep pada langkah 2

Langkah 5 : Kesimpulan dan Penutup

- Membuat refleksi dari kegiatan yang telah dilakukan dan simpulan konsep yang telah dibahas

- Membahas Tugas untuk dikerjakan di rumah

- Pesan moral sebagai penutup
Kelebihan MMP adalah menjembatani antara teacher centered learning ke arah studentcentered learning. Karena, kenyataan di lapangan sangat sulit rasanya mengubah kebiasaan guru yang "berkuasa" menjadi "fasilitator", yang "berbicara" menjadi "pengamat", karena materi yang tersampaikan kepada siswa tidak terlalu memakan banyak waktu dan semakin banyak latihan sehingga siswa mudah dan terampil dengan beragam soal.

Belajar kooperatif dan kemandirian siswa dalam model pembelajaran MMP sangat ditekankan. Pada model pembelajaran MMP siswa diberikan tugas proyek yang berisi sederetan perintah untuk mengembangkan suatu ide atau konsep Matematika.Tugas proyek ini antara lain dimaksudkan untuk memperbaiki komunikasi, penalaran, hubungan interprestasi, keterampilan membuat keputusan, dan keterampilan memecahkan masalah. Tugas proyek ini dapat diselesaikan secara individu (pada langkah seatwork), berkelompok (pada langkah latihan terkontrol) atau bersamasama dalam kelas (pada langkah pengembangan) atau mungkin berupa tugas terstruktur sebagai tugas rumah. Jadi tugas proyek Matematika merupakan suatu tugas yang meminta siswa menghasilkan sesuatu oleh diri siswa sendiri.

Pembelajaran yang berorientasi PAKEMI, yaitu suatu pembelajaran yang mendorong siswa dan guru bersama-sama aktif, penuh dengan daya kreatif, namun juga bahwa proses pembelajaran tersebut haruslah efektif dalam usaha mencapai indicator yang telah ditetapkan, Selain itu yang tidak 
kalah pentingnya ialah bagaimana membawa proses pembelajaran matematika menjadi menyenangkan, terhindar dari anggapan kebanyakan siswa yang berpendapat bahwa matematika suatu pelajaran yang menjemukan, bahwa matematika adalah momok, yang selalu menakutkan, untuk itu seorang guru matematika dituntut untuk selalu memiliki inovatif tertentu dalam mengembangkan suatu model pembelajaran untuk mencapai suatu kompetensi matematika tertentu.

Han (Ma, 2009) mendefinisikan kreativitas dalam bentuk 3P, yaitu (1) creative person, (2) creative process, (3) creative product.Pembagian ini tidak berarti pemisahan yang lepas satu dengan lainnya, tetapi memberi penekanan pada suatu aspak tertentu.Creative person mengacu pada karakteristik personalitas, intelegensi, kemampuan kognitif, motivasi, gaya belajar, gaya berfikir, dll.Sedangkan untuk creative product meliputi ide-ide, solusi, performances, atau produk-produk yang dibangun oleh proses kreatif. Keberhasilan seseorang tergantung dari berbagai faktor.Faktor yang paling berpengaruh adalah motivasi. Prinsip yang dapat membantu menjadi orang yang kreatif adalah berupaya membiasakan diri, dalam: (1) keyakinan diri bahwa selalu ada yang lebih baik, (2) keberanian mencoba, (3) menembus batas, dan (4) membuka diri terhadap orang lain. Keuntungan menjadi orang yang kreatif, ialah: ide baru, bersemangat, menemukan solusi, banyak alternatif, dan perbaikan yang berkelanjutan. Dengan demikian, tujuan penelitian ini adalah: (1) mendeskripsikan proses pembelajaran dengan pendekatan Missouri
Mathematics Project berorientasi PAKEMI pada matakuliah pengembangan pembelajaran matematika sekolah, (2) mendeskripsikan pendekatan Missouri Mathematics Projectberorientasi PAKEMI dalam memotivasi kreativitas mahasiswa Prodi PGSD Universitas Kanjuruhan Malang. Pada matakuliah pengembangan pembelajaran matematika sekolah.

\section{Metode Penelitian}

Jenis penelitian ini adalah Penelitian Tindakan Kelas (PTK), yaitu proses investigasi terkendali untuk menemukan dan memecahkan masalah pembelajaran di kelas, proses pemecahan masalah tersebut dilakukan secara bersiklus, dengan tujuan untuk meningkatkan kualitas proses dan hasil pembelajaran di kelas tertentu (Sa'dun: 2008).Penelitian ini difokuskan pada tindakan-tindakan sebagai usaha untuk meningkatkan keaktifan mahasiswa dalam mengikuti proses pembelajaran mata kuliah "Pengembangan Pembelajaran Matematika". Penelitian ini dilaksanakan di Prodi PGSD Universitas Kanjuruhan Malang.

\section{a. Tahap-Tahap Penelitian}

Penelitian tindakan kelas ini mengikuti empat tahap yang dirumuskan oleh Kurt Lewin (dalam Sa'dun: 2008) yaitu Planning (perencanaa), Action (tindakan), Observation (pengamatan), dan Reflection (refleksi). Dalam penelitian ini, tahapan penelitian disesuaikan dengan prosedur kerja metode pembelajaran MMP dan siklus penelitian tindakan. Prosedur pelaksanaan tindakan dalam penelitian ini mengikuti langkah- 
langkah siklus berspiral yang masingmasing siklus terdiri dari:

Observasi Awal, (2) Perencanaan

Tindakan, (3) Pelaksanaan Tindakan,

(4) Analisa dan Refleksi Data.

(1). Observasi Awal:

- Mengidentifikasi masalah

- Menganalisa masalah

- Merumuskan masalah dan tindakan yang akan dilakukan

(2). Perencanaan Tindakan

- Menentukan pokok bahasan atau materi yang akan digunakan. Pada penelitian ini menggunakan materi dengan kompetensi dasar: "Mengenal dan mampu menerapkan bermacam-macam pendekatan dan model pembelajaran matematika Kontektual dan inovatif dalam proses pembelajaran matematika".

- Merencanakan rancangan pembelajaran yang akan diterapkan di kelas sebagai tindakan dalam siklus. Pada siklus ini direncanakan kegiatan pembelajaran mengikuti langkah model MMP.

- Menyiapkan instrument pendukung pelaksanaan penelitian berupa: Lembar Observasi terstruktur untuk mengamati aktivitas dalam proses pembelajaran yang dilakukan peneliti dan mahasiswa sebagai subyek penelitian

(3). Pelaksanaan Tindakan

Model pembelajaran ini dirancang untuk mencapai satu Kompetensi Dasar yang terdiri dari beberapa indikator. Model pembelajaran ini tidak bisa dilakukan dalam satu pertemuan, Karena perlu adanya beberapa tatap muka dan tugas terstruktur secara berkelompok yang harus dikerjakan di luar kelas dan presentasi hasil kerja kelompok, maka proses pembelajaran pada pertemuam I murni mengikuti langkah model MMP, namun pada pertemuan II sampai pertemuan IV cenderung presentasi dan diskusi hasil kerja kelompok.

(4). Observasi

Team Peneliti terdiri dari 2 orang, salah satunya adalah pengampu mata kuliah Pengembangan Pembelajaran Matematika. Pada saat proses pembelajaran berlangsung salah satu dari anggota team peneliti dibantu oleh seorang mahasiswa bertugas untuk mengamati kesesuaian antara rencana pembelajaran dengan model pembelajaran MMP. Pengamat juga meliput dan menuliskan kejadiankejadian khusus yang terjadi pada saat pembelajaran menggunakan model MMP. Observasi ini juga dilakukan untuk mengetahui motivasi, kerja sama antar kelompok, serta keterampilan mahasiswa dalam mempresentasikan dan menanggapi hasil kerja kelompok lain.

(5)Refleksi

Refleksi dilakukan untuk mencatat atau untuk kekurangandan kelebihan pembelajaran yang dilakukan, serta mengoreksi hal-hal yang perlu diperbaiki pada siklus selanjutnya. refleksi dilakukan 
bersama antara team peneliti dan beberapa mahasiswa terpilih.

b. Kriteria keberhasilan

Yang ditetapkan sebagai kriteria keberhasilan program, yaitu: (1) keberhasilan proses pembelajaran, (2) keberhasilan memotivasi mahasiswa dalam berkreativitas.

\section{Kriteria Keberhasilan Proses}

Keberhasilan proses pembelajaran dalam memotivasi kreativitas dilihat dari:(1) observasi dengan menggunakan lembar observasi terstruktur, (2) Perekaman audiovisual, (3) Catatan lapangan.

\section{1). Observasi}

Dari hasil observasi kegiatan pembelajaran, dicari persentase nilai rata-ratanya dengan rumus :

Persentase Nilai Rata-rata $(\mathrm{NR})=$ $\frac{\text { Jumlah Skor }}{\text { Skor Maksimum }}$ X100 \%

Kriteria taraf keberhasilan tindakan dapat ditentukan sebagai berikut :

Tabel 1. Kriteria penilaian

\begin{tabular}{ll}
\hline Persentase (\%) & kriteria \\
\hline $92-100$ & Sangat baik \\
$75-91$ & Baik \\
$50-74$ & Cukup baik \\
$25-49$ & Kurang baik \\
$50-24$ & Tidak baik \\
\hline
\end{tabular}

\section{2) Perekaman Audio-visual dan}

\section{Catatan Lapangan}

Sedangkan data yang terkumpul melalui perekaman audio-visual dan catatan lapangan berupa data diskriptif kualitatif tidak bisa dibuatkan kriteria yang jelas, sifatnya hanya mendukung data hasil observasi.

\section{Kriteria Keberhasilan Motivasi} Kreativitas

Keberhasilan memotivasi kreativitas mahasiswa dapat dilihat dari produk mahasiswa selama mengikuti proses perkuliahan berupa: (1) Print out review model pembelajaran dan skenario proses pembelajaran matematika SD dengan mengambil satu model pembelajaran kooperatif terpilih, (2) bentuk soal-soal matematika SD dengan indikator tertentu yang melibatkan enam macam kategori (C1-C6) Taxonomi Bloom, (3) Analisis dan diagnosis kesulitan dan kesalahan konsep matematika tertentu bagi siswa SD, (4) CD multimedia pembelajaran matematika SD dengan Kompetenti Dasar tertentu.

\section{Hasil Penelitian dan Pembahasan}

1. Penerapan Pembelajaran dengan Pendekatan MMP Berorientasi PAKEMI pada matakuliah Pengembangan Pembelajaran Matematika Sekolah

Pembelajaran Mata Kuliah Pengembangan Pembelajaran Matematika dalam penelitian ini menggunakan 
Pendekatan pembelajaran MMP berorientasi PAKEMI. Sebelum pelaksanaan pembelajaran dimulai, peneliti terlebih dahulu membuat rencana pembelajaran sebagai persiapan mengajar, kemudian mahasiswa dikelompokkan dalam kelompok-kelompok kecil yang memiliki kemampuan heterogen.Keheterogenan tersebut bermanfaat untuk melatih mahasiswa agar dapat menerima perbedaan dan bekerja sama dengan teman yang berlatar belakang berbeda (Isjoni, 2007:14). Untuk membentuk kelompok jumlah seluruh mahasiswa dalam kelas dibagi menjadi beberapa kelompok yang terdiri dari 3-4 mahasiswa. Pembentukan kelompok dilakukan dengan heterogen sesuai dengan pilihan mahasiswa sendiri. Pelaksanaan pembelajaran dalam penelitian ini meliputi siklus I dan siklus II. Setiap siklus terdiri dari 4 pertemuan. Pembelajaran pada mata kuliah Pengembangan Pembelajaran Matematika pada mahasiswa S-1 PGSD ini menginginkan mahasiswa menghasilkan suatu produk atau hasil kerja. Hasil kerja yang dimaksud di sini merupakan hasil kerja individu maupun kelompokyang harus dihasilkan pada saat dan setelah proses perkuliahan selesai. yaitu berupa: (a) laporan tertulis hasil review macammacam model pembelajaran kooperatif dan memilih salah satunya untuk dibuatkan skenario proses pembelajaran dari salah satu KD matematika untuk Sekolah Dasar, (b) membuat soal tes matematika pada kelas dan KD tertentu dengan berpedoman pada Taxonomi BS. Bloom dan mengujicobakan pada siswa $\mathrm{SD}$, (c) mendiagnosis kesalahan dan kesulitan belajar konsep matematika siswa pada KD tertentu hasil uji coba masing-masing kelompok, (d) membuat multimedia pembelajaran matematika sebagai salah satu alternatif pemecahan hasil diagnosis kesulitan belajar konsep matematika siswa SD dari masingmasing kelompok.

Model pembelajaran ini tidak bisa dilakukan dalam satu pertemuan, Karena perlu adanya beberapa tatap muka dan tugas terstruktur secara berkelompok yang harus dikerjakan di luar kelas dan presentasi hasil kerja kelompok, maka proses pembelajaran pada pertemuam I murni mengikuti langkah model MMP, namun pada pertemuan II sampai pertemuan IV cenderung presentasi dan diskusi hasil kerja kelompok. Berikut dipaparkan pelaksanaan proses pembelajaran dengan model MMP pada pertemuan pertama.

\section{Langkah 1 : Review}

Peneliti sebagai pengampu mata kuliah memberikan informasi tentang konsep-konsep yang terkait dengan pencapaian indicator tertentu untuk mencapai KD yang telah ditetapkan, yaitu "Mengenal dan mampu menerapkan bermacam- macam pendekatan dan model pembelajaran matematika Kontektual dan inovatif dalam proses pembelajaran matematika". Hal ini sesuai pendapat Sardiman (2006:75) dalam kegiatan belajar, motivasi dapat dikatakan sebagai keseluruhan daya penggerak di dalam diri mahasiswa yang menimbulkan kegiatan belajar, yang menjamin kelangsungan dari kegiatan belajar, sehingga tujuan yang dikehendaki oleh subjek belajar itu dapat tercapai. Didukung juga oleh Sanjaya (2006:47) yang mengemukakan bahwa 
mahasiswa akan belajar dengan perhatian penuh manakala memahami tujuan yang harus dicapai serta mengerti apa yang harus dilakukan

\section{Langkah 2 : Pengembangan}

Dengan Tanya jawab diingatkan kembali tentang model - model pembelajaran Inovatif yang pernah dikenal. Dari Tanya jawab ini diperoleh bahwa kebanyakan dari mahasiswa lupa tentang model-model pembelajaran kooperatif yang inovatif untuk meningkatkan keaktifan proses pembelajaran dan hasil pembelajaran matematika.

\section{Langkah 3 : Belajar Kooperatif}

Melakukan proses pembelajaran dengan menerapkan model pembelajaran Kooperatif terpilih, dalam hal ini dilaksanakan model Jigsaw Circle and circle. Kelas dibentuk dalam kelompok kerja kooperatif secara heterogen terdiri dari 4Kelas telah terbentuk menjadi 12 kelompok masing-masing terdiri dari 34 orang. Menurut pendapat Slavin (2009) suatu model pembelajaran dimana mahasiswa belajar dan bekerja dalam kelompok-kelompok kecil secara kolaboratif yang anggotanya 3-4 orang mahasiswa dengan kelompok heterogen merupakan pembelajaran kooperatif.

\section{Langkah 4 : Seatwork}

Masing-masing kelompok diberi kesempatan untuk mencari dan menemukan macam-macam model pembelajaran kooperatif yang mendukung pembelajaran matematika berorientasi PAKEMI, dari berbagai sumber, bisa mengambil dari buku-buku yang relevan atau akses dari internet.

\section{Langkah 5 : Kesimpulan dan Penutup}

Membuat refleksi dari kegiatan yang telah dilakukan dan simpulan konsep yang telah dibahas.Sebagai tugas terstruktur masing-masing kelompok berkewajiban melanjutkan menemukan sebanyak mungkin model pembelajaran yang inovatif dan memilih salah satu model untuk dibuatkan scenario proses pembelajarannya. Sesuai dengan pendapat Degeng (1997) yang menyatakan bahwa pembuatan kesimpulan dari apa yang telah dipelajari perlu dilakukan untuk mempertahankan retensi

\section{Pendekatan MMP dalam Memo- tivasi Kreativitas Pengembangan Pembelajaran Matematika Maha- siswa}

Pelaksanaan pembelajaran berlangsung dengan baik, respon mahasiswa terhadap pembelajaran MMPsangat positif.Hal ini dapat dilihat dari pengamatan pembelajaran berlangsung dengan lembar observasi, catatan lapangan dan hasil refleksi bersama antara team peneliti dan beberapa mahasiswa. Selain itu,dari hasil angket yang diisi oleh 40 mahasiswa, mahasiswa merasa termotivasi untuk mengerjakan tugas-tugas sesuai dengan program yang disepakati pada awal perkuliahan. Pembelajaran dengan pendekatan MMPdapat memotivasi mahasiswa menjadi lebih aktif dan kreatif dalam menyelesaikan tugas-tugas baik pada saat tatap muka maupun tugas terstruktur. Sejalan dengan pendapat Hamalik (2005:108) bahwa pemberian motivasi menentukan tingkat keberhasilan atau gagalnya kegiatan belajar dan belajar tanpa motivasi sulit 
untuk mencapai keberhasilan secara optimal. Pada pembelajaran dengan pendekatan MMP, mahasiswa diarahkan untuk aktif mencari dan mengekplorasi pengetahuan, informasi-informasi penting yang diperlukan untuk mendukung menjawab, menyelesaikan tugas-tugas perkuliahan pengembangan pembelajaran matematika.

Pembelajaran dengan pendekatan MMPdapat meningkatkan rasa percaya diri mahasiswa dan keterampilan berkomunikasi mahasiswa. Adanya interaksi dan diskusi antar mahasiswa, membuat mahasiswa dapat bertukar pikiran dengan mengemukakan setiap pendapat mereka dan saling berbagi pengalaman dan pengetahuan yang mereka miliki.Menurut Pieget (dalam Slavin, 2009:37), bahwa pengetahuan hanya dapat dipelajari dalam interaksi dengan orang lain. Strategi belajar melalui kegiatan mengajarkan kepada teman membuat mahasiswa harus belajar berkomunikasi dengan baik, ketika mahasiswa diberi kesempatan untuk mempresentasikan materi di depan kelas. Untuk berkomunikasi dengan baik, mahasiswa harus mempunyai rasa percaya diri yang kuat.Aktivitas inilah yang dilakukan mahasiswa selama kegiatan belajar berlangsung.Dari aktivitas itu mahasiswa dapat meningkatkan kemampuannya dalam berkomunikasi dan dapat meningkatkan rasa percaya dirinya.Menurut Damon dan Murray (dalam Slavin, 2009:36) bahwa interaksi diantara para mahasiswa berkaitan dengan tugas-tugas yang sesuai meningkatkan penguasaan mereka terhadap konsep kritik.
Pembelajaran dengan pendekatan MMPdapat meningkatkan pengalaman dan pengetahuan mahasiswa dalam belajar.Belajar kooperatif lebih dari sekedar belajar kelompok atau kerja kelompok karena dalam belajar kooperatif ada struktur dorongan atau tugas yang bersifat kooperatif sehingga memungkinkan terjadinya interaksi secara terbuka dan hubungan yang bersifat interdepedensi efektif diantara anggota kelompok (Sugandi, 2002:14).

Motif menjadi aktif pada saat-saat tertentu, terutama bila kebutuhan untuk mencapai tujuan sangat dirasakan/ mendesak (Sadirman:2006). Mahasiswa yang memiliki minat terhadap sesuatu bidang studi tertentu cenderung tertarik perhatiannya dan dengan demikian timbul motivasi untuk mempelajarinya. Berdasarkan hasil angket yang diberikan peneliti kepada masing-masing mahasiswa dan hasil observasi mahasiswa menunjukkan, mahasiswa dapat mengikuti dan melaksanakan langkahlangkah pembelajaran pendekatan MMPdengan baik dan menunjukkan bahwa mahasiswa sangat senang dan antusias pada saat mengikuti pembelajaran matematika. Secara kuantitatif keberhasilan motivasi kreativitas mahasiswa berkisar antara 77,42\% hingga $87,08 \%$ dalam kategori baik.

\section{Simpulan}

Proses pembelajaran dengan Pendekatan MMP dapat memotivasi kreativitas mahasiswa dalam matakuliah Pengembangan Pembelajaran Matematika, hal ini dapat dilihat dari hasil berikut: 
1) Print out review model pembelajaran dan skenario proses pembelajaran matematika SD dengan mengambil satu model pembelajaran kooperatif terpilih dari masing-masing kelompok, rata-rata mahasiswa dapat mengerjakan dengan kategori baik dengan rata-rata prosentase keberhasilan 83,58\%;

2) Tugas kelompok membuat soal tes matematika pada kelas dan KD tertentu dengan berpedoman pada Taxonomi BS. Bloom dan mengujicobakan pada siswa SD ratarata mahasiswa dapat mengerjakan dengan kategori baik dengan rata-rata prosentase keberhasilan $84,17 \%$;

3) Mendiagnosis kesalahan dan kesulitan belajar konsep matematika siswa pada kompetensi dasar tertentu hasil uji coba masing masing kelompok rata-rata mahasiswa dapat mengerjakan dengan kategori baik dengan rata-rata prosentase keberhasilan 77,42\%;

4) Tugas kelompok membuat multimedia pembelajaran matematika sebagai salah satu alternatif pemecahan hasil diagnosis kesulitan

Berdasarkan hasil pengamatan, analasis dan refleksi pada kegiatan ini, peneliti memiliki saran-saran yang ditujukan kepada:
1. Kalangan Dosen Pengampu mata kuliah di Prodi S-1 PGSD Universitas Kanjuruhan, khususnya pengampu mata kuliah Pengembangan Pembelajaran, hendaknya kreatif dan inovatif dalam memotivasi mahasiswa untuk mengekplorasi dan mengembangkan pengetahuan yang dimiliki terkait dengan mata kuliahnya untuk menciptakan suatu produk yang mendukung kelancaran proses pembelajaran di sekolah.

2. Penelitian ini jauh dari sempurna, penulis berharap ada penelitian lanjutan yang dapat mendukung atau mengembangkan hasil penelitian ini, baik pada mata kuliah yang sama atau pada mata kuliah yang lain.

\section{Pustaka Rujukan}

Akbar, S. dan Sriwiyana, H. 2008. Pengembangan kurikulum dan Pembelajaran: Ilmu Pengetahuan Sosial, Yogyakarta: Cipta Media.

Degeng, I.S. 1997. Strategi Pembelajaran: Mengorganisasi Isi dengan Model Eraborasi. Malang: IKIP dan Ikatan Profesi Teknologi Pendidikan Indonesia

Hamalik, O. 2005. Perencanaan Pengajaran Berdasarkan Pendekatan Sistem. Jakarta: PT.Bumi Aksara Isjoni dan Ismail,A. 2007. Model-Model Pembelajaran Mutakhir. Yogyakarta: Pustaka Pelajar

Ma.H.H. 2009. The Effect Size of Variables Associated With Creativity: A Meta-Analysis 
Creativity Research Journal.

(Online), 21 (1), 30-42,

(http://personal.stevens.edu/ rchen/creati

vity/creative\%20person.pdf),

diakses 5 Juni 2012.

Moleong, L. 2002. Metodologi penelitian

kualitatif. Bandung: PT. Gramedia

Wiasarana Indonesia.

Rohaeti, A. 2009.Pengaruh Penerapan

Model Pembelajaran Missouri

Mathematics Project (MMP) ter-

hadap Kemampuan Pemecahan

Masalah Matematika Siswa SMA.

Pendidikan Matematika FPMIPA

UPI Bandung: Tidak diterbitkan

[Online]

Tersediahttp://repository.upi.

edu/operator/upload/ta_mtk_05579

2_chapter2.pdf

Sanjaya, W. 2006.Strategi Pembelajaran.

Jakarta: Kencana Prenada Media

Group.

Sardiman, 2006.Interaksi dan Motivasi

Belajar Mengajar.Jakarta: PT

RajaGrafindo Persada.

Slavin, R.E. 1995. Cooperative Learning:

Theory, Research, and Practice.

Second Edition. Massachusetts:

Allyn and Boston Publishers.

Sugandi, A.I. 2002. Pembelajaran

Pemecahan Masalah Matematika

Melalui Model Belajar Tim

Assisted Individualization (TAI)

pada SMU Bandung. Tesis pada

PPS UPI Bandung: tidak

diterbitkan

Tim PPPG Matematika. 2004. Beberapa

Teknik, Model dan Strategi Dalam

Pembelajaran Matematika(Bahan

Diklat guru Pengembangan SMP.

Yogyakarta: PPPPG Matematika. 